\title{
In vitro Efficacy of Botanicals and Biocontrol Agents against Early Leaf Blight in Tomato
}

\author{
S. Pavan Kumar ${ }^{*}$, M.K. Mishra ${ }^{2}$ and P.R. Mishra ${ }^{3}$ \\ ${ }^{1}$ College of Agriculture, Orissa University of Agriculture and technology, \\ Bhubaneswar-751003, India \\ ${ }^{2}$ Department of Plant Pathology, ${ }^{3}$ Department of Entomology, OUAT, \\ Bhubaneswar-751003, India \\ *Corresponding author
}

\begin{tabular}{|c|c|}
\hline & A B S T R A C T \\
\hline $\begin{array}{l}\text { Ke y w o r d s } \\
\text { Karanj, Alternaria } \\
\text { solani, } \\
\text { Pseudomonas } \\
\text { fluorescens, } \\
\text { Trichoderma viride }\end{array}$ & $\begin{array}{l}\text { Early blight is potentially destructive disease in tomato occurring on the oldest leaves as } \\
\text { small, brownish which are due to foliar blight disease and it was caused by a foliar fungal } \\
\text { pathogen Alternaria solani. The disease causes considerable yield as well as post-harvest } \\
\text { losses. A. solani produced blackish, fluffy mycelium with septate, beaked conidia on PDA } \\
\text { Eight plant extracts and four biocontrol agents were evaluated following poison food } \\
\text { technique and dual culture. Garlic+Neem+Datura and only garlic extract induced } 100 \% \\
\text { growth reduction at } 10 \% \text { and } 20 \% \text { concentrations for the test pathogen followed by Datura }\end{array}$ \\
\hline Article Info & $76.43 \%$. Neem leaf extract had approximately no effect on the inhibition of radial growth \\
\hline $\begin{array}{l}\text { Accepted: } \\
12 \text { November } 2018 \\
\text { Available Online: } \\
10 \text { December } 2018\end{array}$ & $\begin{array}{l}\text { of Alternaria solani with only } 1.4 \% \text { and } 8.44 \text { growth inhibition in } 10 \% \text { and } 20 \% \\
\text { concentration, Pseudomonas fluorescens recorded maximum growth inhibition (79.35\%) } \\
\text { against A. solani followed by Trichoderma viride inhibited ( } 78.97 \%) \text { growth of A. solani. } \\
\text { Least growth inhibition observed for Trichoderma hamatum }(69.99 \%) \text { among four bio- } \\
\text { agents. }\end{array}$ \\
\hline
\end{tabular}

\section{Introduction}

Tomato is belongs family solanaceae. It is herbaceous annual plant with bisexual flowers. The fruit is true berry. It is warm season crop. The plant cannot withstand frost and high humidity. It is one of the most important "protective foods" because of its special nutritive value Tomato is a good source of vitamins $\mathrm{A}, \mathrm{C}$ and $\mathrm{E}$ and minerals that are very good for body and protect the body against diseases (Taylor, 1987). A general climate of Odisha is warm and humid with mild winter and a hot summer which is very much conducive for rapid growth of pathogenic micro-organisms. Like other crops this crop is also subjected to several diseases caused by fungi, bacteria, viruses, nematodes and abiotic factors (Balanchard, 1992). The crop suffers from a number of foliar diseases such as early blight, also called Alternaria leaf blight (Alternaria solani), late blight (Phytophthora 
infestans), Septoria leaf spot (Septoria lycopersici), Gray mold (Botrytis cinerea) and leaf mold (Fulvia fulva). Among the fungal diseases, early blight also known as target spot disease incited by Alternaria solani (Ellis and Martin) Jones and Grout, Fusarium blight incited by Fusarium oxysporum f.sp. lycopersici and Curvularia leaf spot incited by Curvularia lunata. Early Leaf blight in tomato is the most destructive disease as it accounted for $78 \%$ yield loss at $72 \%$ disease intensity (Datar VV and Mayee CD 1981). The pathogen of the disease has been documented as A. solani globally as well as in India (Gomes SMDTP et al., 2010).

\section{Materials and Methods}

In vitro evaluation of plant extracts for management of causal pathogen

The present investigation was carried out to evaluate different plant species for the possible presence of fungi toxicant properties by poisoned food technique. The list of botanicals used in the study is presented in Table 1. Hundred grams of fresh leaf material was taken and cut into small pieces, $20 \mathrm{ml}$ of 5 per cent acetone was added and the samples were ground thoroughly. Different plant extracts of varying concentrations i.e. 10.0 and 20.0 percent were tested in three replications. In vitro evaluations of leaf extracts were done against $A$. solani using Potato dextrose agar medium. The leaf extracts were mixed to the medium by proper stirring and poured to Petri plates and allowed for solidification. Seven $\mathrm{mm}$ disc from twelve days actively growing culture was transferred aseptically using cork borer to the Petri plates containing leaf extracts. The PDA plates without any plant extracts served as control. The plates were incubated at $27 \pm 1^{\circ} \mathrm{C}$ for 10 days and the colony diameter was recorded. Per cent inhibition was worked out according to the equation of Vincent (1947).
$I=\frac{C-T}{C} \times 100$

Where, I = Per cent inhibition of the mycelium $\mathrm{C}=$ Growth of the mycelium in control $\mathrm{T}=$ Growth of the mycelium in treatment.

\section{In vitro evaluation of Neem oil for management of causal pathogen}

The experiment was carried out by taking $1 \%$ oil concentration for management of mycelia growth. The appropriate concentration of oil after emulsifying with Tween 20 was mixed with sterilized potato dextrose agar media and thoroughly mixed with media. Twenty $\mathrm{ml}$ of media was poured into each Petri dish and allowed for solidification.

\section{In vitro evaluation of bio control agents}

The efficacy of biocontrol agents were tested against casual organism by dual culture technique. Biocontrol agents like Trichoderma viride, Trichoderma hamatum, and Trichoderma harzianum, Pseudomonas fluorescens were tested against the fungus. The fungal antagonist was grown in potato dextrose agar media ad bacterial antagonist in nutrient agar media to get fresh active culture for the experiment (Table 2).

\section{Dual culture technique}

About $20 \mathrm{ml}$ of potato dextrose media for fungus and nutrient agar media for bacteria was poured into petri dishes and allowed to cool down. The fungal mycelial disc $(5 \mathrm{~mm})$ was transferred to one end of the plate and fungal antagonist culture disc placed opposite to it leaving 5-6 $\mathrm{mm}$ distance from the periphery of the plates. In case of bacterial antagonist, the bacterium was streaked at one side of the plate and fungal culture disc at other side of the plate. Each treatment was replicated thrice. The inoculated plates were 
taken. The data analyzed statistically. The efficacy of bio control agents were expressed as percentage inhibition of mycelia growth over control and calculated as (Vincent, 1947).

$$
\mathrm{I}=\frac{\mathrm{C}-\mathrm{T}}{\mathrm{C}} \times 100
$$

$\mathrm{I}=$ Percent inhibition, $\mathrm{C}=$ Radial growth in control, $\mathrm{T}=$ Radial growth in treatment

\section{Statistical analysis}

The experiments were done under controlled laboratory conditions, and the data were analyzed following completely randomized design (CRD).

\section{Results and Discussion}

\section{Alternaria solani}

Significant difference in growth inhibition was observed among all the tested plant extracts in 10 and $20 \%$ concentrations. Garlic+Neem+Datura and only garlic extract induced $100 \%$ growth reduction in both the concentration. Datura leaf extract $(10 \%$ and $20 \%$ ) reduced the growth of test pathogen to $65.17 \%$ and $76.43 \%$ respectively which was next to Combination and Garlic plant extracts, Turmeric also reduced moderately the growth of test pathogen in both concentration. Neem leaf extract at par with Karanj leaf extract with negligible growth inhibition in $10 \%$ concentration Neem leaf extract had approximately no effect on the inhibition of radial growth of Alternaria solani with only $1.4 \%$ and $8.44 \%$ growth inhibition in $10 \%$ and $20 \%$ concentration respectively (Table 3 ). These findings has been reported by Abhijit Ranaware et al., (2010), Yadav and Pathak (2011), Sallam (2011), this was in contrary with reports obtained by Deepti Sadana et al., (2015) who reported Azadirachta indica inhibiting complete mycelial growth of Alternaria solani.

Fungal and bacterial bioagents were also tested in dual culture method for the inhibition of the growth of foliar pathogen i.e. Alternaria solani. Radial growth $(\mathrm{mm})$ was recorded when growth in control plate reached $85 \mathrm{~mm}$ and the data present in Table 4. Among three fungal bio agents tested are Trichoderma viride recorded maximum growth inhibition (78.97\%) followed by Trichoderma hamatum (75.33\%) against Alternaria solani, Trichoderma hamatum was found to be less effective only reducing approximately $70 \%$ growth of the pathogen. Pseudomonas fluorescence inhibited $79.35 \%$ growth of Alternaria solani (Table-4, Plate$3)$.

Table.1 List of plant extracts used

\begin{tabular}{|l|l|l|c|}
\hline SI. No. & Common name & Botanical name & Plant parts used \\
\hline $\mathbf{1}$ & Garlic+Neem+Datura & Combination & Clove+Leaf \\
\hline $\mathbf{2}$ & Datura & Datura stramonium & Leaf \\
\hline $\mathbf{3}$ & Garlic & Allium sativum & Clove \\
\hline $\mathbf{4}$ & Mint & Menthe piperita & Leaf \\
\hline $\mathbf{5}$ & Onion & Allium cepa & Bulb \\
\hline $\mathbf{6}$ & Turmeric & Curcuma longa & Rhizome \\
\hline $\mathbf{7}$ & Azadirachtin oil & Azadirachtaindica & Neem seed \\
\hline $\mathbf{8}$ & Neem & Azadirachtaindica & Leaf \\
\hline $\mathbf{9}$ & Karanj & Pongamiapinnata & Leaf \\
\hline
\end{tabular}


Table.2 Biocontrol agents

\begin{tabular}{|c|c|c|}
\hline SI.No. & Biocontrol agents & Place of Collection \\
\hline 1 & Trichoderma viride & $\begin{array}{l}\text { Department of Agriculture Entomology, College } \\
\text { of Agriculture, OUAT, Bhubaneswar. }\end{array}$ \\
\hline 2 & Trichoderma hamatum & $\begin{array}{l}\text { Department of Plant pathology, College of } \\
\text { Agriculture, OUAT, Bhubaneswar. }\end{array}$ \\
\hline 3 & Trichoderma harzianum & $\begin{array}{l}\text { Central Horticultrual Experiment Station, } \\
\text { Bhubaneswar. }\end{array}$ \\
\hline 4 & Pseudomonas fluorescens & AICRP on ground nut, Bhubaneswar. \\
\hline
\end{tabular}

Table.3 In vitro evaluation of plant extracts against $A$. solani

\begin{tabular}{|c|c|c|c|c|c|}
\hline \multirow[t]{2}{*}{ SI. No. } & \multirow[t]{2}{*}{ Treatments } & \multicolumn{2}{|c|}{$10 \%$} & \multicolumn{2}{|c|}{$20 \%$} \\
\hline & & $\begin{array}{l}\text { Mean radial } \\
\text { growth }(\mathbf{m m})\end{array}$ & $\begin{array}{l}\text { Per cent } \\
\text { inhibition }\end{array}$ & $\begin{array}{l}\text { Mean radial } \\
\text { growth }(\mathbf{m m})\end{array}$ & $\begin{array}{l}\text { Per cen } \\
\text { inhibition }\end{array}$ \\
\hline 1 & Garlic+Neem+Datura & $0(0.71)$ & 100 & $0(0.71)$ & 100 \\
\hline 2 & Datura leaf extract & $24.73(5.02)$ & 65.17 & $17.23(4.20)$ & 76.43 \\
\hline 3 & Garlic bulb extract & $0(0.71)$ & 100 & $0(0.71)$ & 100 \\
\hline 4 & Mint leaf extract & $50.27(7.16)$ & 29.20 & $45.43(6.78)$ & 37.85 \\
\hline 5 & Onion bulb extract & $43.77(6.65)$ & 38.35 & $38.10(6.21)$ & 47.88 \\
\hline 6 & $\begin{array}{l}\text { Turmeric rhizome } \\
\text { extract }\end{array}$ & $32.10(5.71)$ & 54.79 & $26.43(5.19)$ & 63.84 \\
\hline 7 & Azadiractin oil & $50.77(7.16)$ & 28.49 & $20.5(4.74)$ & 71.96 \\
\hline 8 & Neem leaf extract & $70.00(8.40)$ & 1.41 & $66.93(8.21)$ & 8.44 \\
\hline 9 & Karanj leaf extract & $68.87(8.33)$ & 3 & $39.77(6.34)$ & 45.6 \\
\hline 10 & $\mathrm{~T}_{10}($ Control $)$ & $71.00(8.45)$ & - & $73.10(8.58)$ & - \\
\hline & $\operatorname{SEm}( \pm)$ & 0.09 & & 0.08 & \\
\hline & $\operatorname{CD}(5 \%)$ & 0.3 & & 0.2 & \\
\hline
\end{tabular}

*Figures in the parentheses indicate $\sqrt{(x+0.5)}$ transform values

Table.4 Efficacy of fungal and bacterial Bio-control agents against radial growth of foliar pathogen of tomato

\begin{tabular}{|l|l|l|}
\hline \multirow{2}{*}{ Treatments } & \multicolumn{2}{|c|}{ Alternaria solani } \\
\cline { 2 - 3 } & $\begin{array}{l}\text { Mean radial } \\
\text { growth(mm) }\end{array}$ & Per cent inhibition \\
\hline Trichoderma viride & 18.33 & 78.97 \\
\hline Trichoderma hamatum & 26.16 & 69.99 \\
\hline Trichoderma harzianum & 21.5 & 75.33 \\
\hline Pseudomonas fluorescens & 18 & 79.35 \\
\hline T $_{\mathbf{5}}$ (Control) & 87.16 & - \\
\hline
\end{tabular}


Plate.1 (10\%conc) Efficacy of various plant extracts against radial growth of Alternaria solani

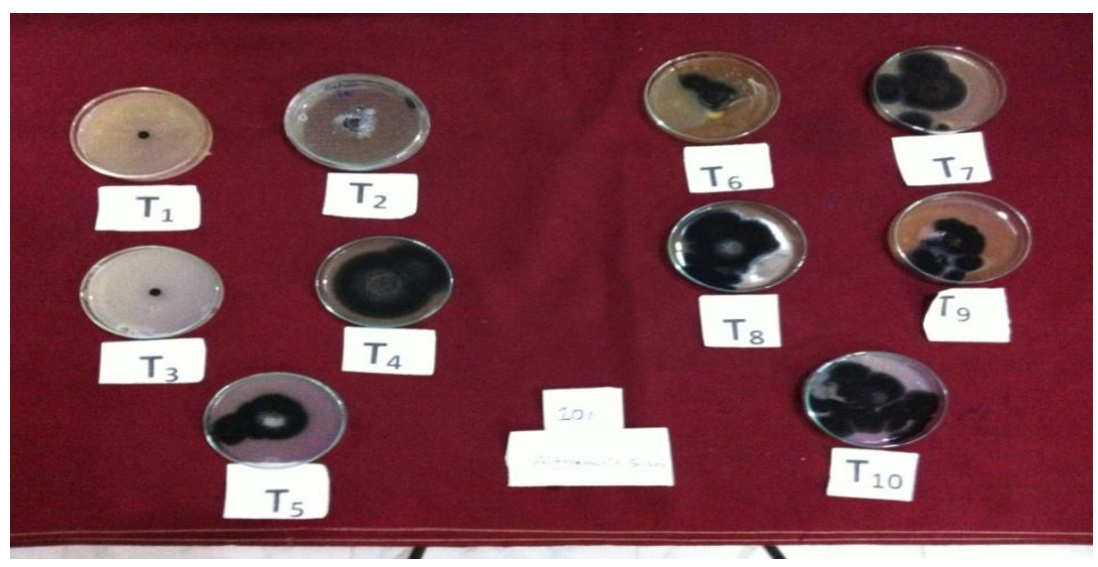

Plate.2 (20\%conc) Efficacy of various plant extracts against radial growth of Alternaria solani

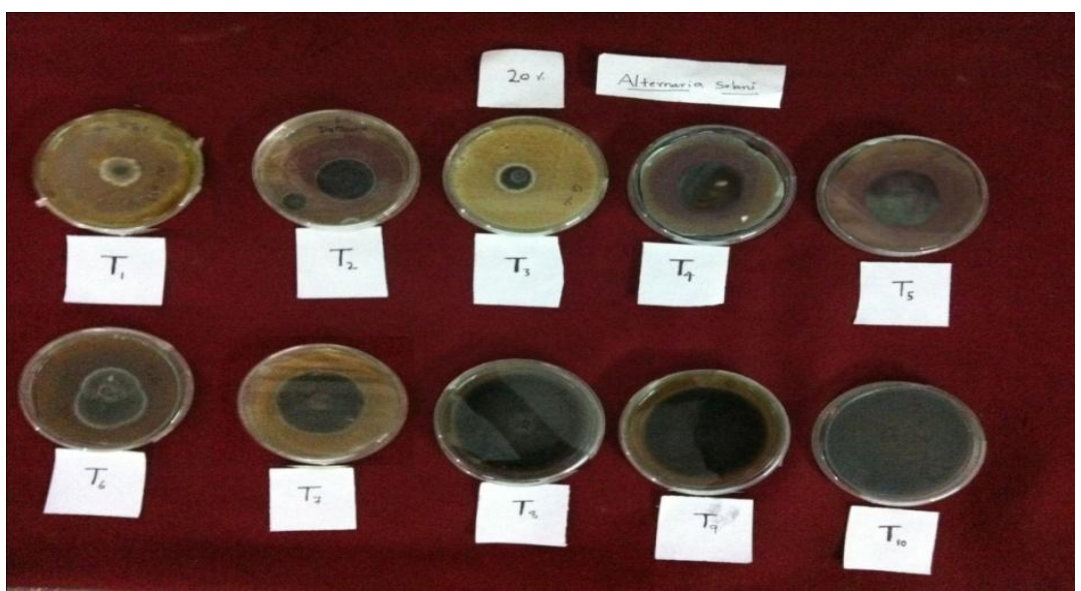

$\mathrm{T}_{1}$-Garlic+Neem+Datura(combination), $\mathrm{T}_{2}$-Datura leaf extract, $\mathrm{T}_{3}$ Garlic bulb extract, $\mathrm{T}_{4}-\mathrm{Mint}_{\text {leaf extract, }} \mathrm{T}_{5}-\mathrm{Onion}$ bulb extract, $\mathrm{T}_{6}$-Turmeric corm extract, $\mathrm{T}_{7}$-Azadiractin oil $\mathrm{T}_{8}$-Neem leaf extract, $\mathrm{T}_{9}$-Karanj leaf extract, $\mathrm{T}_{10}$-Control.

Plate.3 Efficacy of various bioagents against growth of Alternaria solani

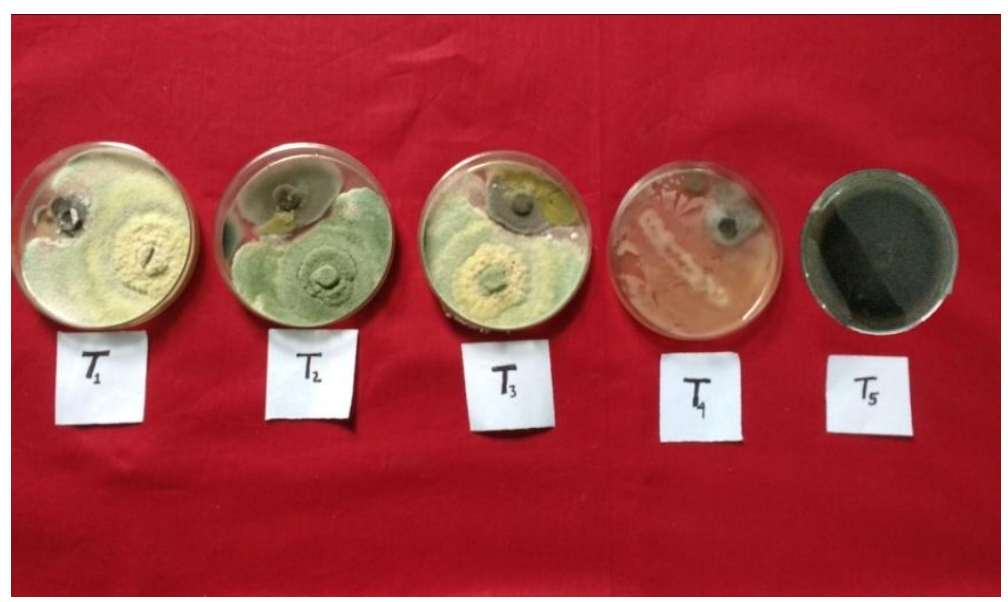

$\mathrm{T}_{1^{-}}$Trichoderma viride, $\mathrm{T}_{2^{-}}$Trichoderma hamatum, $\mathrm{T}_{3^{-}}$Trichoderma harzianum, $\mathrm{T}_{4^{-}}$Pseudomonas fluorescens, $\mathrm{T}_{5-}$ Control 
This finding has been reported by Deepak Khulbe and Dubey (2001), Somnath Koley et al., (2015).

It is concluded that this investigation reveals that among all bio agents (garlic, Neem and Datura) combination and only garlic bulb extract, Trichoderma viride, Pseudomonas fluorescens are effective to management the Alternaria solani under lab conditions. Present study helpful for further investigation in vivo management of Early blight.

\section{References}

Abhijit, R, Vrijendra. S, Nandini, N. 2010. In vitro antifungal study of the efficacy of some plant extracts for inhibition of Alternaria carthami fungus. Indian Journal of Natural Products and Resources. 1(3): 384-386.

Balanchard, D. 1992. A color atlas of tomato diseases. Wolfe Pub. Ltd., Brook house, London, P. 298

Datar, V.V, Mayee, C. D. 1981. Assessment of losses in tomato yield due to the early blight. Indian Phytopath, 34: 191-195.

Deepa, K, Pant, Anil Kumar, A. K, Garg, G. K. 2003. Prospective use of certain plant against some important fungal and bacterial plant pathogens and insect pests. Proc of Indian Phyto Path Soc. and National Symposium on pl. pathogens diversity and in relation to $\mathrm{pl}$. health, Jan 16-18.

DeeptiSadana and Nidhi Didwania. 2015. Bioefficacy of fungicides and plant extracts against Alternaria solani causing early blight of tomato International Conference on Plant, Marine and Environmental Sciences (Kuala Lumpur).
Dohroo, N. P, Verma S. 2003. Evaluation of botanicals in vitro against Fusarium oxysporum $f$. sp. pisi causing wilt of pea. Pl. Dis. Res. Ludhiana, 18(2): 131-134.

Ellis, J. B, Martin, G. B.1882. Macrosporium solani. American Naturalist. 64(8): 283.

Ganie, S. A, Pant, M. Y, Ghani Ashiq Hussain Lone, Qaisar Anjum, S.M, Razvi. In vitro evaluation of plant extracts against Alternaria brassicae (Berk.) Sacc. causing leaf spot of mustard and Fusarium oxysporum f.sp. lycopersici causing wilt of tomato. Academic Journals, 8(37), 1808-181.

Gomes SMDTP, Carneiro EDB, Romano EP, Teixeira MZ, daCosta ME, Vasconcelos JCG. 2010. Effect of biotherapic of Alternaria solani on the early blight of tomato-plant and the in vitro development of the fungus. dInt J High Dilution Res 9:147-155.

Nashwa M. A. Sallam, 2011. Control of tomato Early Blight disease by certain plant extracts, plant pathology Journal10 (4): 187-191, 2011.

Somnath, K, Shyama, S. M, P. C, Kole. 2015. In vitro efficacy of bio-control agents and botanicals on the growth inhibition of Alternaria solani causing early leaf blight of tomato International journal of bioresource, Environment and Agricultural sciences (IJBEAS),1(3): 114-118, 2015.

Taylor, J. H (1987). Text of lectures delivered at the national workshop on fruit and vegetable seedlings production held at NIHORT 9-13.

Vincent, J. M 1947. Distortion of fungal hyphae in the presence of certain inhibitors. Nature, 159: 850-850.

\section{How to cite this article:}

Pavan Kumar, S., M.K. Mishra and Mishra, P.R. 2018. In vitro Efficacy of Botanicals and Biocontrol Agents against Early Leaf Blight in Tomato. Int.J.Curr.Microbiol.App.Sci. 7(12): 13401345. doi: https://doi.org/10.20546/ijcmas.2018.712.163 